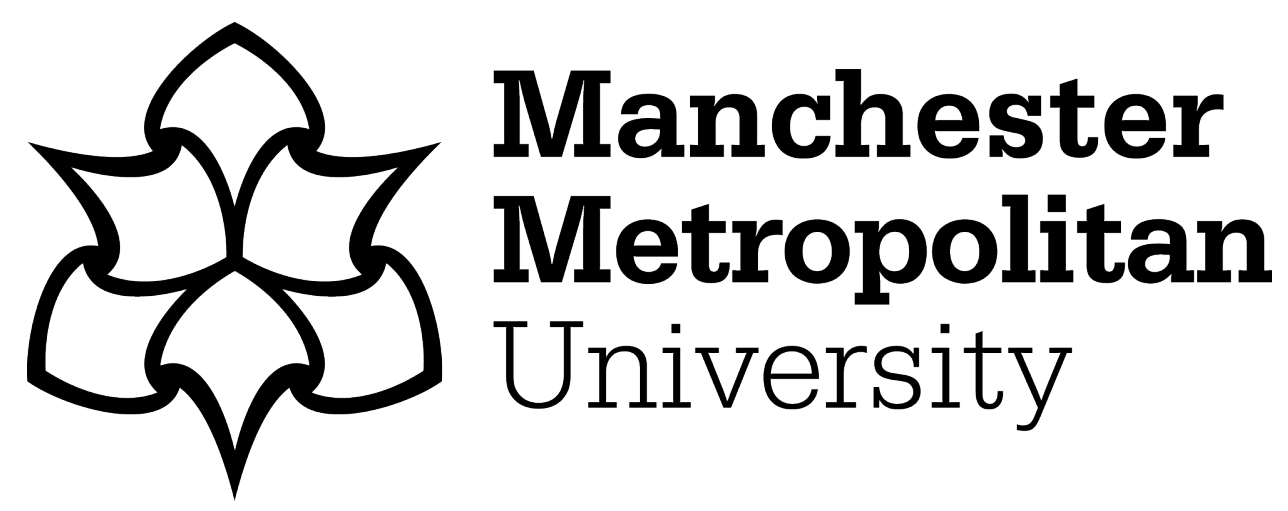

Pashby, Karen ORCID logoORCID: https://orcid.org/0000-0002-9967-8262, Da Costa, Marta, Sund, Louise and Corcoran, Su ORCID logoORCID: https://orcid.org/0000-0002-3513-2770 (2020) Resourcing an Ethical Global Issues Pedagogy with Secondary Teachers in Northern Europe. In: Teaching and Learning Practices that Promote Sustainable Development and Active Citizenship. IGI Global, pp. 47-66. ISBN 9781799844020

Downloaded from: https://e-space.mmu.ac.uk/627051/

Version: Accepted Version

Publisher: IGI Global

DOI: https://doi.org/10.4018/978-1-7998-4402-0.ch003

Please cite the published version 
Chapter submitted for inclusion in book as:

Pashby, K., da Costa, M., Sund, L. and Corcoran, S.L. (2020) 'Resourcing an Ethical Global Issues

Pedagogy with Secondary Teachers in Northern Europe.' In Saúde, S., Raposo, M.A., Pereira, N. and Rodrigues, A.I. (Eds.) Teaching and Learning Practices that Promote Sustainable

Development and Active Citizenship. IGI Global. pp. 47 - 66. DOI: 10.4018/978-1-7998-4402-0

\title{
Resourcing an ethical global issues pedagogy with secondary teachers in northern Europe
}

\author{
Karen Pashby \\ Manchester Metropolitan University, United Kingdom \\ Marta da Costa \\ Manchester Metropolitan University, United Kingdom \\ Louise Sund \\ Örebro University, Sweden \\ Su Corcoran \\ Manchester Metropolitan University, United Kingdom
}

\begin{abstract}
In this chapter, the authors report on a participatory research project with secondary school teachers in England, Finland, and Sweden that aimed to explore the possibilities for ethical global issues pedagogy in classrooms. The project had three integrated stages: i) development and delivery of a workshop for teachers based on a synthesis of theoretical work in critical global citizenship education and environmental and sustainability education, and introducing Andreotti's (2012) HEADSUP tool; ii) classroom visits and reflective interviews with teachers where the workshop material was applied and adapted; and iii) drafting, reviewing, piloting, and publishing online a resource to support teacher practice. Findings show teachers are inspired and committed to engaging with deep ethical pedagogical approaches to global issues. However, in order to be able to take up critical approaches in the classroom, teachers require resources and spaces where they can engage with theory and research, reflect, experiment and exchange information with other teachers.
\end{abstract}

Keywords: Global Citizenship Education, Environmental and Sustainability Education, Education for Sustainable Development, HEADSUP, Sustainable Development Goal 4 Target 7, Coloniality in Education

\section{INTRODUCTION}


The launch of the Sustainable Development Goals (SDGs) in 2015 marked a new period of international efforts in education for sustainable development (ESD). Building from Goal 4, quality education, Target 4.7 defines a clear agenda, stating that by 2030, all learners are to have acquired the knowledge and skills needed to promote sustainable development, including through education for sustainable development and global citizenship. According to UNESCO (2016, p. 288), target 4.7 "touches on the social, humanistic and moral purposes of education and their impact on policies, curricular content and teacher preparation" more than any other target, and captures "the transformative aspirations of the new development agenda" by explicitly linking education to other SDGs.

Unlike the Millennium Development Goals (MDGs), the SDGs are aimed at all signatory countries, which means countries in the "Global North' are being called on to actively promote change in their own contexts. This raises a question regarding the extent to which teachers in the north of Europe are resourced to meet this target. Research has found that efforts to promote global citizenship education (GCE) and ESD have been largely superficial (e.g. Andreotti, 2006; Huckle \& Wals, 2015) and are informed by a neoliberal agenda that focuses on promoting individualism and competition (e.g. Jickling \& Wals, 2008; Van Poeck \& Vandenabeele, 2012). There have also been strong critiques of the ways that environmental education can reproduce Westerncentric colonial systems of power by disconnecting environmental issues from historical and political contexts (e.g. Blenkinsop et al., 2017; Matthews, 2011). Similarly, global learning initiatives including those supporting global citizenship seem to have largely taken soft approaches, stepping over complex and ethical issues, particularly those around power inequality and on-going colonial legacies (Andreotti, 2006; Shultz \& Pillay, 2018). Consequently, scholarship indicates in many cases education about global issues has arguably served to perpetuate the reproduction of the global systems of power that have caused these problems in the first place (e.g. Andreotti, 2011; Pashby, 2018). Reflecting on the United Nations Decade for Education for Sustainable Development (UNDESD), Huckle \& Wals (2015) argue for an approach to teaching and learning about sustainability as linked strongly to broader global learning goals. They maintain such an approach must be deeply theoretically grounded in order to move beyond tokenism and superficial approaches. Further, Wals (2015) argues for stronger attention in research and practice regarding the tendency for teachers to find tackling ethical issues uncomfortable and in support of "ethical" pedagogy that opens up spaces for ethical considerations and moral dilemmas (p. 16).

There is further evidence of support for a critical approach, this time on the part of young people. The International Youth White Paper on Global Citizenship (2017) was written by students (ages 14-18) from five continents with input from thousands of their colleagues. This included contributions from students in Sweden. Presented at the UNESCO Global Forum on Global Citizenship Education, it puts forward the recommendation that education addresses inequities by including marginalised voices and explicitly taking up unequal power relations and colonial history and oppression (see also Shultz et al., 2020). Given the scholarship calling for greater attention to how teaching about global issues is implicated in ongoing colonial relations of power, we argue it is essential to take seriously a theoretically grounded approach to considering how teachers in 'Global North' contexts are resourced to facilitate this important work.

Other discussions have engaged beyond Westerncentric models of global learning such as Sharma's (2020) work on the contributions of Japanese educator Daisaku Ikeda and Indian activist Mathatma Ghandi to global learning. Our project sought to specifically take up post- and de-colonial theoretical engagements concerned with the ways global learning is complicit in the modern-colonial matrix of power. Andreotti (2011) argues for the importance of applying theories that directly engage with coloniality as a way to open up possibilities for relating 'otherwise' through theorizing non-coercive relations with the 'Others' of global learning. These 'Others' have historically been the occupation and production of Western humanitarism. For example, Mignolo (2011) speaks about the shine and shadow of 
modernity where a light side includes aspects of society greatly valued in modern society and international development such as seamless progress organized through rational consensus within and between sovereign nation-states. However, this 'light' side ultimately depends on a dark side of modernity, which is coloniality, and is evidenced through on-going over-exploitation of resources and people resulting in war, epistemic racism, dispossession, destitution and genocide. In intervening into how learning about global issues reflects this dualism, Andreotti (2014) refers to modernity's trick. This is when well-intended acts of altruism promote bringing more people into the 'light side' without realizing the 'light side' of modernity depends on the dark side and thereby foreclosing the possibility to actually make intelligible and work towards changing the conditions of coloniality in which we are all implicated.

Andreotti's (2012) HEADSUP tool intervenes in 'modernity's trick' by supporting critical reflexive engagements with representations of global issues, particularly those North-South engagements with local populations who are structurally marginalized. Originally inspired by the troubling KONY 2012 phenomenon $^{2}$, the HEADSUP tool provides a list of historical patterns often reproduced in education initiatives in the 'Global North' thereby enabling educators and learners to start conversations about:

- Hegemony - justifying superiority and supporting domination;

- Ethnocentrism - projecting one view as universal;

- Ahistoricism - forgetting historical legacies and complicities;

- Depoliticisation - disregarding power inequalities and ideological roots of analysis and proposals;

- Salvationism - framing help as the burden of the fittest;

- Un-complicated solutions - offering easy solutions that do not require systemic change;

- Paternalism - seeking affirmation of authority/ superiority through the provision of help and the infantilization of recipients (Andreotti, 2012, p. 2).

Importantly, the HEADSUP tool is not a checklist that can solve all global problems nor does it provide a perfect approach; however, it can engage dominant practices straight on, so learners in 'Global North' contexts can problematize and work beyond dominant narratives about global issues that reproduce an 'us' and a 'them' (Andreotti et al., 2018).

There is limited research on the pedagogical potential in using the tool, particularly in formal education. Grain \& Lund (2016) applied HEADSUP to examine social justice issues inherent to in-service learning, and Kuleta-Hullboj (2016) used HEADSUP to analyse interviews with employees from Polish NGOs. There is some literature on the employment of critical approaches to global issues in formal education. Sund (2016) adapted HEADSUP to analyse classroom and interview data looking into how upper secondary school teachers in Sweden use critical approaches in teaching global issues, but did not examine its application in classroom practice. While teachers in her study could problematize a focus on western perspectives and saw the importance of historical context to inform sustainability issues, her study suggested teachers could use resourcing support to promote a more critical approach. Similarly, other research found teachers are able to adopt critical approaches in their teaching (e.g. Madsen, 2013; Niens \& Reilly, 2012; Reilly \& Niens, 2014; Truong-White \& McLean, 2015). Nevertheless, the research has also shown that teachers are highly constrained by a variety of factors. Niens \& Reilly's (2012; see also Reilly \& Niens, 2014) study of critical GCE approaches in Northern Ireland classrooms (ages 8-9 and 12-13) identified time as a key barrier to teachers, as well as a lack of knowledge and appropriate resources, reflexive practice, and dialogue with colleagues. The lack of relevant training and resources has also been highlighted as a key factor hindering teachers' ability to promote critical approaches to global issues in schools (Niens \& Reilly, 2012; Reilly \& Niens, 2014; Truong-White \& McLean, 2015), 
and can lead to the adoption of instrumental and superficial approaches. Madsen (2013), who monitored the unfolding practice of Education for Sustainable Development (ESD) in primary and secondary schools in Denmark and Ireland, found that teachers were struggling with time constraints in a loaded curriculum, particularly in relation to assessment and accountability demands. Furthermore, without the support and space for dialogue with other teachers, particularly in schools where global issues are not a key curricular discipline, teachers become isolated, and "in the long run the position of lone agents of change is clearly difficult to maintain" (Madsen, 2013, p. 3779). Teachers in that study were looking for further resourcing and support. No study of which we are aware has examined the extent to which HEADSUP can be a useful resource for teachers.

To summarize, there is broad consensus on the importance of including global issues in education and significant theoretical discussions regarding the importance of a critical approach. However, there is a lack of research into a) how to enact critical scholarship across the two fields of ESD and GCE and b) to what extent teachers in the northern Europe are currently resourced and open to engaging a critical approach.

If teachers are to meet a key aim of GCE as defined by UNESCO (2014, p. 16), "Support learners to revisit assumptions, world views and power relations in mainstream discourses and consider people/groups that are systematically underrepresented/ marginalized", then we need to ensure they are resourced to do so. In an exploratory and participatory project that involved 26 secondary teachers (of students aged 14-18) in England, Finland, and Sweden, we investigated the extent to which the HEADSUP tool could support a critical approach to teaching about global issues. The Teaching for sustainable development through ethical global issues pedagogy: Participatory research with teachers project was funded through the British Academy's Tackling the UK's International Challenges Programme and ran for 15 months (January 2018- March 2019).

In this chapter, we review the process and methodology of the project and describe a synthesis of some key findings. We also share an overview of the practice-based output of the project, a co-created teacher resource. This project brought the realities of classroom life into conversation with deeply theoretical discussions in the fields of environmental and sustainability education and global citizenship education, intervening in an assumed chasm between theory and practice. We suggest this project is as an example of how spaces can be opened in order to bring together researchers and teachers and promote a theoretically grounded praxis and a praxis informed theory.

\section{OVERVIEW OF THE PROJECT AND METHODOLOGY}

There were four main aims to the project (Pashby et al, 2019, p. 5):

1. To bridge critical research in the areas of critical global citizenship education (GCE) and environmental and sustainability education (ESE)

2. To bring together academics and teachers to conduct timely research into the opportunities and barriers to teachers teaching about global issues in secondary schools

3. To share and assess the pedagogical usefulness of an analytical tool designed to make visible interlocking systems of oppression inherent to the study of global issues

4. To develop a resource that could be used by both teachers and students to enable critical engagement with global issues in secondary-level classrooms

The aims were actioned through three inter-related phases to the project: delivering workshops to teachers, observing classes and interviewing teachers, and developing a teacher resource. 
In advance of Phase One, the researchers identified key common critiques in the fields of critical GCE and ESE. They responded to calls in both fields for attention to ethical complexities and for a centering of colonial relations of power, selecting Andreotti's (2012) HEADSUP tool as a common framework. In phase one, March - May 2018, 26 secondary and upper secondary school teachers (teaching students within the age range of 14 to 18) attended workshops in England (Birmingham, Manchester, London), Finland (Helsinki), and Sweden (Stockholm), with a relatively even spread across the three national contexts. Locations were selected based on where researchers had networks who could support recruitment under the tight project timeline, and for being in transportation hubs to facilitate a range of urban, sub-urban and rural-based teachers to attend. We invited teachers through emails via teacher networks and using social media (facebook and twitter). While some workshops had less participants, content and opportunity for discussion was consistent (see Pashby et al, 2019).

Reflecting the demography of teachers across the profession, nine males and seventeen females participated. They ranged in teaching experience from new to very experienced teachers with the largest cohort in the six to ten-year range. Three of the participants work in a school dedicated to global issues (in Sweden) while the largest cohort identified they had up to five years of experience teaching global issues. The sustainable development goals were a priority for all the teachers, and they all indicated they teach about global issues in their practice and/or participate in school-wide activities related to global learning. Swedish teachers taught across a variety of subjects within social studies and humanities (e.g., geography, history, economics, civics, entrepreneurship) and two taught natural science. In Finland, teachers taught across social studies (civics, ethics, geography, psychology), one taught geography and biology, another taught mathematics, and two taught languages (English, French, Swedish). In England, reflecting the strongest curriculum links and also some targeted recruitment to find participants within a short period of time, most participants taught Geography while two taught Religious Education and/or Civics.

Teachers were asked to read the International Youth White Paper on Global Citizenship (2017) in advance of the workshop and to complete a pre survey regarding opportunities and barriers inherent to their experiences of teaching global issues. The teachers introduced themselves to one another by sharing an artefact (a lesson plan, resource, teaching story) they have used in their teaching of global issues and/or sustainable development. Next, researchers shared the rationale for the project, drawing on key critiques from the scholarly literature and reviewing the UNESCO goal for GCE on which the project is based. To explore the concept of critical GCE, the researchers facilitated a set of short activities on critical literacy and distinguished between soft and critical GCE (Andreotti, 2006). They then presented and engaged with the HEADSUP tool, which was the main focus of discussion. Participants were invited to reflect on how it connected to their own teaching using the reflexive tool (see Pashby \& Sund, 2019b, p. 5; 2020a, p. 318 ) and were given time to work in pairs or small groups to discuss other ideas for its applicability in classrooms.

Phase Two (April to June 2018) involved visits to classrooms followed by reflective interviews with teachers. Two teachers in the UK and three in Sweden volunteered initially to be observed using ideas from the workshop in their classrooms. Following the observation, the researchers conducted a semistructured interview asking what from the workshop connected to their lesson and how they felt the lesson went. They often referred to student work. In some lessons, teachers directly adapted HEADSUP to their practice, and in other cases, they applied concepts from the workshop in a more holistic way (e.g., by exploring multiple and contradicting perspectives) or specifically (focusing on one element of HEADSUP) (see Pashby \& Sund, 2019a).

Phase Three (July 2018 to February 2019) involved creating, piloting, and finalising a teacher resource as well as doing a thematic analysis of the data sets. In July 2018, we invited five teachers in the UK who had been particularly interested in the workshop material to attend a resource development workshop in Manchester. There they shared further reflections on HEADSUP having had a chance to use it and think 
about it since the workshop. Then they worked together to create question-sets for a resource that could support other teachers to deepen their global issues pedagogy, based on their experiences and reflections of using and adapting the HEADSUP tool. They also discussed how they would like the resource to be organised. Dr. Pashby created a draft resource based on their inputs along with inputs generated by teachers across the workshops and from Dr. Sund. Initial findings from the first two phases were reviewed and synthesized into a set of guiding principles with input from project data in all three national contexts. These guiding principles were used to focus and organise the draft resource. This draft resource was reviewed by advisor Ms. Ilona Taimela (a global and sustainability education expert, researcher, and teacher from Finland) at a project meeting in August, when a firm draft was finalised. Next, we invited all participants who attended workshops to review the draft resource. Several sent feedback. One participant went so far as to seek further feedback from colleagues in his school and regional network. In England (autumn 2018) and Finland (winter 2019), Dr. Pashby conducted two additional classroom observations and interviews of participants who volunteered to pilot specific activities from the resource in their classrooms. Finally, a layout and final version of the resource based on all feedback collected was compiled with the help of a graphic designer into a publishable booklet. The booklet was translated and published online in a Finnish and Swedish version (Pashby \& Sund, 2019b).

We considered the methodology participatory, recognising along with Cornwall (2008) how that term can conflate what is a wide range of distinct approaches. In our case, the project was participatory in the sense that it involved the community to be studied working with academics (Hansen et al, 2001). Also, the project design ensured that what is largely theoretical scholarship directly engaged with the day to day lives and experiences of teachers and their classrooms (Lau \& Still, 2014). We were committed to supporting praxis by bringing teachers into a conversation about both theoretically deep and practically rich issues relating to global citizenship and sustainable development, and we have used that engagement with practice to feed back to theoretical discussions (e.g., Sund \& Pashby, 2020). While teachers' participation was centered in the project, the researchers determined the research questions and conducted the analysis. Researchers shared the main aims of the project explicitly with the participants who were invited to participate in and take from the project what best suited their professional practice and context during the course of the study. We analysed the data to identify key themes, and findings and outputs were shared with participants.

Rather than study teachers at a distance, the aims and design of the project sought to correlate and produce both important empirical findings as well as a tangible resource to promote practice. The datasets created through the project included: pre- and post-workshop surveys, transcripts of all of the discussions at the workshops and at the resource development meeting, pictures of written materials (including some artwork) produced by teachers at the workshop when starting to apply HEADSUP, field notes from the classroom observations, and transcriptions of the reflective interviews following the observations. We analysed the data using thematic analysis. The surveys enabled some direct feedback from teachers about their current practice and the extent to which the workshop related to their work, while the workshop discussions and reflective interviews provided valuable 'teacher talk' (Biesta et al., 2017). What teachers share about their practice provides insight into their own sense-making and evidences wider discourses and sources (e.g., policy, research, public opinion). Importantly 'teacher talk' can reflect what "shape[s] their expectations and ambitions, their views about what is possible and what not, both in regard to themselves and their actions, and with regard to the colleagues they work with and the students they work for" (p. 40). Our sample is small and self-selected, involving teachers interested in coming to a workshop and participating in the project. It is by no means a generalisable sample. However, we have collected some rich data. Findings will direct further research in the area and were put into practice through the production of the teacher resource.

\section{KEY FINDINGS}


The pre-survey findings map onto to the findings in the studies previously reviewed. Teachers expressed they are particularly inspired by the SDGs to teach about global issues, but also that they feel overwhelmed by the vast range of educational materials on offer. While there were relevant curriculum links in all contexts, some teachers also mentioned the curriculum as hindering their ability to teach about global issues. A participant from Finland talked about a "crowded curriculum", with other teachers in England also commenting on the difficulty of fitting attention to global issues and the SDGs around the syllabus and preparation for examinations. At the same time, a recurrent theme in the findings was teachers' motivation for this work and a desire to support their students in engaging with new perspectives to think "outside their bubble". Teachers across the contexts reported specific characteristics of the demographics of their class (e.g., homogenous, white-middle class) along with ignorance, misconceptions and stereotypes as barriers to their work. However, these challenges were also factors that motivated them, and many of the participants believe students are eager to be challenged with complex ideas.

In the post-workshop surveys, some teachers expressed the workshop reinforced what they are currently doing whilst others said it raised new ideas. They remarked that the HEADSUP tool is "an interesting way to question our subjects" (Swedish participant), and repeatedly highlighted the importance of questioning assumptions and mainstream perspectives. Teachers also thought the tool would be helpful in responding to the perceived ignorance or blind-spots on the part of the students. Teachers from all three national contexts indicated they would use the tool in their planning and adapt their teaching style to include "an emphasis on questioning" [Manchester], "being mindful of [their] own practice" [Stockholm], and "deepening and extending the topics" [London]. Many felt they could use the HEADSUP tool as a possible jumping-off point. Nevertheless, teachers identified a key challenge for them would be adding complexity to their teaching without getting overwhelmed. Some teachers also raised a concern about being 'too negative' with students when challenging mainstream and misguided charity approaches. Some teachers raised the issue of taking-up a critical approach in lessons while not discouraging active citizenship. As the critical nature of the HEADSUP tool means it takes time to implement and requires a sensitive approach, several participants expressed support for the development of a resource that could complement what they are already doing.

The discussions among teachers at the workshop and resource development meetings also elicited very relevant insights into the perceived importance of an ethical and complex pedagogical approach to teaching global issues in schools. Participants discussed the danger of charity-based approaches that promote deficit views and uncomplicated solutions to development issues. A participant from the Birmingham workshop commented:

You have things like every year like Children in Need ... and they completely reinforce those sort of things [in HEADSUP]. There's always a video, and they're always drawing the worst-case examples that stimulate people to give more charity money. It just reinforces the idea of you have to give them charity and they're underdeveloped and we have to support them. It's a completely wrong way of doing it. There are better examples you can sometimes use... and you're not just giving them money, giving support, it's about education. We can sometimes use the example, 'okay if you can provide rather than give them like loads of food and water and give them the education to develop that, and then have that and then stimulate things like rainwater harvesting, improve this', uh, I don't think there's enough of those sort of examples in the mainstream. You can teach about them in a lesson but then I think [the charity model is] reinforced in what I see.

Additionally, participants recognised a dominance of a Western/Eurocentric representation of development issues that creates an 'us' versus 'them' dichotomy. Applying HEADSUP to reflect on her own teaching, a teacher in Helsinki noted many approaches "promote saviour/victim relationality". She also questioned whether the Tanzania project at her school was based on the production of a "feel good" 
factor and remarked she would take "a more in-depth look at current teaching material. They usually present the problems through Western/Northern Europe mindset”.

Building from the survey data, workshop discussions highlighted possibilities but also tensions in the teaching of global issues through an ethical approach. Teachers spoke about tensions around privilege and power, and highlighted the demographics of the classroom (teachers and students) have an important impact on how they approach global issues and how class discussions develop. For example, in the Stockholm workshop, a teacher talked about polarization in the classroom, where a smaller group of students frequently center questions of feminism and colonialism while others, particularly White male students, resist this. Similarly, at the resource development meeting in England, a participant pointed out the tension inherent to an over-representation of white, middle-class people in the teaching profession as well as in education research including this project, "we're all looking at marginalised groups, and we're all white people".

Another interesting point of tension was brought up by a participant from England during the Resource Development Day. A discussion emerged regarding how to encourage a complex and critical approach when students often expect a conclusive answer. One participant suggested "we need to allow kids to [...] be able to both arrive at an answer, but not necessarily a solution", noting students expect a complete answer at the end of a lesson or unit. Another participant responded in agreement, noting "confusion is a really important part of learning". He shared his experience of teaching with HEADSUP and the realization he had that nuance is really important and engaging for students and cannot be side stepped by packaging a lesson into a positive message. He also articulated the importance of reflecting on positionality, commenting that the students' ability to "identify and break down their [own] viewpoint is kind of paramount to them being able to then break down other's viewpoint".

The classroom observations and post-lesson reflective interviews with seven teachers ( 3 in Sweden, 3 in England, 1 in Finland) provided an opportunity to capture how teachers took ideas from the workshop and put them into practice (see also Pashby \& Sund, 2019a, 2020a, 2020b). Teachers engaged in the classroom applications phase of the project found ways to adapt the HEADSUP tool, finding it useful across contexts. Some of the teachers also found it helpful to apply aspects from the workshop as principles for their practice. Anna (pseudonyms used for all participants) in Sweden, as well as Laura in England, for example, found that raising critical reflective questions can be a helpful way to support teachers deepen and promote criticality in their practice. In the interviews following up the sessions, the teachers were generally impressed by the critical engagement of their students across different levels and abilities. Laura, in England, was happy to see how her application of ideas from the workshop prompted a critical approach from all students, even a "weaker student". They could identify multiple perspectives while deepening concepts learned in previous classes. Similarly, Sam, also in England-who adapted HEADSUP to a question set that prompted students to develop their own questions - was impressed with the work of "lower performing students" who came up with strong alternative questions. However, teachers also reflected on the need to allow time for students to fully grasp the complexities within the curriculum timeframe. Both Laura and Sam felt they would try in future to allow more time for this type of work.

In line with their workshop discussions, teachers who participated in the classroom observations employed critical approaches to global issues and their pedagogical strategies engaged directly with taking up mainstream narratives. They adapted the HEADSUP tool to their class level and session content, in order to promote the identification of marginalised perspectives on understandings of development and development issues. This is exemplified by Anna's class in Sweden, a year 12 social sciences class [ages $18-19$ ] at a school that specializes in global issues. The lesson aimed to build on prior learning to promote a critical consideration of mainstream notions of development. Anna wanted to make dominant and non-dominant perspectives on development visible. She aimed to promote "a more 
balanced picture", building on concepts such as reflexivity, multidimensional views of development, homogenous/heterogeneous groups, and central/peripheral values. For this lesson, where students were presenting findings from their fieldwork in India on farming issues, Anna specifically focused on examining ethnocentrism. She felt this focus would help students reflect not only on their case study, but also on how their own background impacts their view of development. During the observation, the researcher noticed students spoke about the extent to which they were employing a "Western view of development" in their assessment of the well-being of a population who relies on agriculture. Students discussed that being able to support one's family on what one produces could be more important than a purely economic rationale of earning or producing more because they could. This same group spoke about the extent to which they had a quite one-dimensional view of poverty, noting that 'being poor' was very contextual.

In England, Sam adapted the HEADSUP tool to fit his year 9 [ages 13-14] Geography class on the Kibera area of Nairobi as part of a larger unit on Kenya. His aim was to encourage students to think of multiple perspectives that can be used to frame an issue. Through prompting the student to pose alternative questions, he aimed to open-up a more complex and non-static approach. He was impressed by the alternative questions developed by the students, and highlighted a few when reading them over during the interview after the session: "That's a great alternative question, to go from 'who's in charge of the situation' to 'who can change or influence people', it's like spot on!'. In the interview, the researcher also shared a moment she had observed when one of the students was answering the question about viewpoints and said "it depends on how one's viewpoint is framed...people could be coming from different perspectives". Sam noticed the student wrote a strong alternative question for that section: "who decides what the viewpoint on the situation is".

Based on the work that teachers had contributed at the workshops and based on initial thematic findings from the surveys, teacher discussions, and initial set of classroom visits and interviews, the research team identified a set of key principles to direct practice (Pashby et al., 2019, p. 4):

- Global issues are complex and we need pedagogical approaches that take up rather than gloss over these complexities.

- Environmental issues are deeply tied to social, political, cultural and economic inequalities; it is essential to link such issues to historical and present-day colonial systems of power.

- Connecting to all species in our world requires an ethical stance towards both the deep issues threatening us all and the differently experienced impacts of environmental issues.

- Classrooms are important spaces for raising questions. There are solutions to promote and actions to be taken. Re-thinking and unpacking are themselves important actions. When schools and wider community activities promote charity appeals, classrooms can support students to deeply engage with and identify tensions and possibilities.

- Reflexivity must be encouraged and developed. Deeply understanding nuances and considering tensions and paradoxes is as important to global citizenship as is taking a specific action (or deciding not to take an action). These must go hand in hand.

These, along with practical applications suggested by the teachers, were then used to inform the development of teacher resource for supporting complexity and ethical discussions in the teaching of global issues. The next section provides an overview of the resource, introducing the main sections, and some key findings from the piloting of the resource in two classrooms.

\section{A RESOURCE FOR SECONDARY TEACHERS}


Teaching for Sustainable Development Through Ethical Global Issues Pedagogy: A Resource for Secondary Teachers (Pashby \& Sund, 2019b) provides a resource to support reflexive teaching practice and to inform critical examinations of global issues in class. Building on participants' work applying Andreotti's (2012) HEADSUP tool to their global issues pedagogy, the resource has been created with teachers, based on their experience and reflections of teaching about global issues in the classroom. It provides suggestions for practice before, during, and after students learn about a particular global issue. Importantly, the resource is meant to support teachers in their current practice, rather than directing practice through a 'how-to' guide. The main sections include:

\section{Reflections for teachers:}

This reflexive tool helps teachers themselves critically review the materials and pedagogies that currently support and could in the future support their global issues pedagogy. Reflexive questions are informed by HEADSUP (Pashby \& Sund, 2019, p. 5):

- Hegemony - In my teaching, how can I raise inherited and taken-for-granted power relations? Do I identify mainstream discourses and marginalised perspectives/ norms and trends?

- Ethnocentrism - In my teaching, can lessons address that there are other logical ways of looking at the same issue framed by different understandings of reality/ experiences of the world?

- Ahistoricism - In my teaching, how can I avoid treating an issue out of context as if it just happened now? How are today's issues tied to on-going local and global trends/patterns/narratives?

- Depoliticisation - In my teaching, how can I ensure students don't treat issues as if they are politically neutral? Who is framing the issue and who is responsible for addressing it? Who are the agents of change and what mechanisms for change are available?

- Salvationism - How can we take up good intentions to want to help others through generosity and altruism without reinforcing an us/them, saviour/victim relationship?

- Universalism - How can we address people's tendency to want a quick fix? How can we grapple with the complexities, root causes, and lack of easy solutions?

- Paternalism - How can we put aside our egos and self-interest? Are we open to being wrong, to not being the ones who know best?

\section{Orienting learners to the global issue:}

This section focuses on what are mainstream and marginalised perspectives. Supporting students orientation around a global issue, there are several activities that help students understand and critically examine what are the mainstream perspectives on the issue being studied (see Pashby \& Sund, 2019, p. $6)$.

\section{Exploring the issue:}

This activity can be used to analyse a campaign directed at students that relates to any global issue, and to critically engage with sources of information. It provides a set of evaluative questions that operationalise HEADSUP, and support the analysis of resources (see Pashby \& Sund, 2019, p 7). 


\section{Breaking down an issue and identifying key challenges:}

This section includes a series of three question sets that could support the students in their inquiries and be adapted to suit different materials the teacher is already using. This section provides the product of the adaptation of HEADSUP by the teachers and researchers to a language that can be used across all levels of secondary schools. In the first one, HEADSUP was adapted to a list of key ideas with related key questions (Pashby \& Sund, 2019, p. 8):

- Background - what have been the main causes of this situation?

- Perspectives - what are the different viewpoints of this situation?

- Fairness - who is the most impacted by this issue?

- Leadership - who is in the best position to make a change for everyone?

- Responses - what is one good option for improving this situation?

- Future - what do you think this place will be in the future?

The activity both prompts students to answer these questions, but also to consider alternative questions that might dig deeper. The idea is to encourage critical literacy and to critically engage with questions as well as answers.

The second set of questions also provides an adaptation of HEADSUP that is focused on themes and related key questions (Pashby \& Sund, 2019, p. 9):

- Power - who is impacted, involved in power?

- Perspectives - mainstream and marginalised

- Context - interconnections and interdependencies

- Responses - improving the situation

- Equity - is there potential to centre the needs of those who are marginalised?

- Future and Sustainability - looking forward.

The third set provides questions that can support a critical analysis of a visual representation of global issues (Pashby \& Sund, 2019, p 10). The questions centre around the following key themes: Stretch and Challenge; Power; Responses; Perspectives; Future; Background; Equity. There is also a suggestion for applying these in a mind-map and a hand-out to enable this.

\section{Responses and Actions Checklist:}

This check-list can be used after students have studied an issue in order to consider future implications of their conclusions (see Pashby \& Sund, p. 11).

There is also an appendix with hand-outs for use with students.

The resource has been well received by the teachers who were involved in the process of developing it. Several of them have presented it to colleagues in their local regions. The teachers commented on the resource's applicability as "a simple, practical way for a teacher to implement this research" (Subject Leader of Geography), with a strong potential to support teaching and learning. As the Religion and Education and Citizenship teacher put it, "it explores and scaffolds the exploration of complex, and massively important, ideas essential to effective and well informed global citizens. A great resource for anyone wanting to teach global citizenship in a fresh, exciting and well-structured way". Teachers were also enthusiastic about the "clear link to the sustainable development goals, allowing students and teachers to be actively involved in meeting one (Subject Leader of Geography)", particularly as "these are 
exactly the skills and abilities that students need to develop into today's global world" (Geography teacher).

\section{PILOTING THE RESOURCE IN TWO CLASSROOMS}

As mentioned, parts of the resource were piloted by teachers before the final draft was completed. One of the school visits in England took place at an academy in South London that serves a very diverse demographic, with a majority of students of racialized backgrounds and many of first generation living in England. Jill, a Geography teacher who attended the workshop in London, reported at the resource development meeting in Manchester a couple of months later that she had taken HEADSUP directly into her teaching across Years 7, 8, 10 and 12 [ages 11-17]. She came up with what she thought were more straight-forward questions that aligned with HEADSUP, keeping the original words to preserve the acronym intact. Jill also made use of the Kony 2012 video, which was the campaign to which Andreotti's HEADSUP tool was developed as a response. The video was a global phenomenon produced by the NGO Invisible Children, and aimed to raise awareness and funds to bring Uganda's warlord Joseph Kony to justice. It was shared online millions of times and was later criticized for presenting an uncomplicated perspective among other issues (see Von Engelhardt \& Jansz, 2014).

By using her adaptation of the HEADSUP questions to analyse the video, Jill found that, while students found it challenging, they were very engaged:

I think that this gave them kind of responsibility or some sort of ownership for the issue because it was very challenging.... We structure things so much that they don't feel like they're actually doing the work, so something like this, it was tough, and we did get through it and they were so invested in it in the lesson and able to, at the end of a 50 minute lesson, walk away understanding like maybe there's more to these situations than we think: There's certain factors [i.e., HEADSUP concepts], that we can look for that would suggest that maybe I'm not getting the whole story. So with my Year 8s [ages 12 - 13] it was less about them comprehending these [HEADSUP concepts] and more about understanding the dynamic that like news, media, stuff like that, stories sometimes are very simple, and we need to sort of listen critically and figure out not necessarily what we're not being told but that maybe there's room to explore further.

In particular, she thought they really understood Un-complicated solutions and Salvationism.

The classroom visit by the researcher occurred several months later and involved two year 11 [ages 15$16]$ lessons. This was the second time Jill was doing this activity that would be included in the resource, and this time she took more time at the beginning of the lesson to help students identify and recognise what mainstream perspectives are, particularly dominant perspectives, by piloting the orientation activities in the resource. She found this helped them to understand why it is a problem to oversimplify an issue and fail to look more broadly at its roots. She then led the students through using the HEADSUP adapted question-set to analyse Kony 2012 as a text, encouraging students to articulate a critical understanding of the way the video presents the issue. She was happier with using the orientation activity together with the exploring the issue activity. She felt this is something she will continue to use in her practice, and she expressed hopes to come back to the ideas across lessons and units, to give students time to deepen their understanding and apply the concepts.

The final school visit and resource piloting took place in one of the larger cities in Finland, with a small class of 12 students [ages 16-17] in a school focused on the disciplines of mathematics and technology. The teacher, Kaisa, piloted the resource in her Ethics class. In a previous lesson, she had asked students what they knew about climate change and from what sources. She then probed a discussion about how different sources have different benefits and limitations to raise the question "from whose point of 
view?". She found the students answered "from everyone's point of view", so she thought, "OK, maybe we need something more concrete to understand this topic". She developed an activity where students sorted recent headlines from Finland's national newspaper into different categories: a) good news versus bad news; b) news related to economics, sports, or culture; and, c) news about Finland, Western countries, or developing countries. She felt that activity added complexity to their understanding of their own perspectives "because they actually know that there is not news from, for example, the developing countries' point of view; and that there's mainly Western and of course mostly from Finland what we get and what we know". Also, they struggled with categorizing the news headlines as good or bad: "because it's not always clear". This activity was added to the Orienting learners to the global issue: Mainstream and marginalised perspectives section of the teacher-resource.

On the day of the researcher's visit, Kaisa adapted one of the question-sets developed in Manchester at the resource development meeting (Breaking Down an Issue 2) to unpack the issue of climate change. In addition, she modelled how to use the question set to develop a mind map (this was added to the resource) and asked them to use the questions to create a mind-map in groups. She was very happy with the way the group work went. She found they were really using the question-set, noting, "they kept holding the question-set sheet in their hands and going back to it...looking at them over and over" as they set about writing mind-maps:

They were talking a lot. And I think mainly they were talking about clever things, like good ideas, and... One was saying something and one was saying something else. And it was like developing. It was not like that one is right and one is wrong. That can also happen sometimes.

Another important theme emerging from Kaisa's lesson and her reflections on it is the importance of interfering in single-stories that become mainstream and unquestioned. She noted that all of the students wanted to talk about Donald Trump as a climate denier and some made quite generalised statements about America: "And I said 'but in the US there is not only one point of view or one person who is acting. It's also different political points of view, different people, different situations, it's so huge"'. In addition to this, in the process of answering the questions and composing a mind-map, she was able to help students challenge a singular view of 'developing countries', considering them beyond a single-story of aidreceiving countries, something that is considered more deeply below in relation to themes cutting across the classroom visits data.

\section{KEY INSIGHTS FROM THE PROJECT}

The Sustainable Development Goals have provided an opportunity for countries in the 'Global North' to create spaces where students critically engage with global issues, addressing, rather than glossing over, their complexity. While working with a small sample of only 26 teachers, the project has demonstrated that these teachers are deeply committed to, and have an important role in, promoting critical approaches to global issues in schools. Building on and reinforcing findings from other studies, teachers in this project identified as key barriers to their practice time, resources, and school and classroom demographics. However, even though the findings cannot be generalized, the project has also given indication that there are effective strategies that can be put in place to support the teachers. Particularly, opening up spaces for teachers and researchers to come together, in a way that combines theory and practice and promotes critical discussions allows for teachers to use different theoretical tools to critically reflect on what they are already doing. Additionally, it provides room for discussions with colleagues and researchers where experiences can be shared and strategies exchanged. The project also opened up a space for teachers to experiment and reflect. This seemed helpful as teachers adapted their materials and approaches after workshops and interviews. We would also argue that the teacher resource emerging from the discussions, class observations and reflections has provided a tool for other teachers to use, adapt and reflect on. 
Teachers employed different strategies to add complexity to the examination of global issues, and found that "anchoring" activities to key concepts and promoting a reflection on positionality was an effective way to promote nuanced discussions. Using the original or an adapted version of the HEADSUP tool appeared to be successful in supporting students to identify mainstream perspectives. Furthermore, when alternative or marginalised perspectives were raised, there was also a desire on the part of some teachers to complexify these, and resist replacing one alternative view for another/ reach a final answer. This raises a very important question about how a culture of pluralism - where all perspectives are treated equallymay work against an approach that engages with tensions between perspectives. Also, teachers were less consistent in the ways they applied HEADSUP to draw out colonial systems of power although several of the teachers used it to intervene into 'us' versus 'them' and deficit views. That is an area for further and on-going research and practice. The project findings have also fed back into the researchers' theoretical work in the area of coloniality as praxis (see Sund \& Pashby, 2020).

The project provides a snapshot of practice, but not a final answer as practice continues and evolves as does theory. Future research should focus on how the approach proposed in this work could be used to engage with other levels of education and subject areas. Also, the project raises the importance of wider classroom practices that establish a pedagogical culture that supports this type of work, including antiracist pedagogies. Concerns about how different groups of students will react to raising these issues of power were clearly expressed by teachers in this study and requires further research and support. It is important that research and practice of ethical global issues pedagogy continues to focus on opening up spaces and resourcing teachers at pre-service and in-service levels, as well as providing on-going reflection on the part of classroom teachers and researchers.

\section{REFERENCES}

Andreotti, V. (2006). Soft vs. critical global citizenship education. Policy and Practice: A Development Education Review, 3, 40-51. Retrieved from

https:/www.developmenteducationreview.com/issue/issue-3/soft-versus-critical-globalcitizenship-education

Andreotti, V. (2011). Actionable Postcolonial Theory in Education. New York, New York: Palgrave Macmillan.

Andreotti, V. (2012). Editor's preface: HEADS UP. Critical Literacy: Theories and Practices, $6(1), 1-3$. Retrieved from

http://criticalliteracy.freehostia.com/index.php?journal=criticalliteracy\&page=article\&op=view \& path $\% 5 \mathrm{~B} \% 5 \mathrm{D}=109 \&$ path $\% 5 \mathrm{~B} \% 5 \mathrm{D}=84$

Andreotti, V. (2014). Actionable Curriculum Theory: AAACS 2013 Closing Keynote. Journal of the American Association for the Advancement of Curriculum Studies 10, 1-10.

doi: 10.14288/jaaacs.v10i1.187728

Andreotti, V., Stein, S., Sutherland, A., Pashby, K., Susa, R., \& Amsler, S. (2018). Mobilising different conversations about global justice in education: toward alternative futures in uncertain times. Policy \& Practice: A Development Education Review, 26, 9-41. Retrieved from https://www.developmenteducationreview.com/issue/issue-26/mobilising-differentconversations-about-global-justice-education-toward-alternative 
Biesta, G., Priestley, M., \& Robinson, S. (2017). Talking about education: Exploring the significance of teachers' talk for teacher agency. Journal of Curriculum Studies, 49(1), 38-54. doi: 10.1080/00220272.2016.1205143

Blenkinsop, S., Affifi, R., Piersol, L. \& Sitka-Sage, M. (2017) Shut-up and listen: implications and possibilities of Albert Memmi's characteristics of colonization upon the 'natural world'. Studies in Philosophy of Education, 36(3), 349-365. Retrieved from https://eric.ed.gov/?id=EJ1140177

Cornwall, A. (2008). Unpacking 'Participation': models, meanings and practices. Community Development Journal, 43(3), 269-283.

doi: $10.1093 / \mathrm{cdj} / \mathrm{bsn} 010$

Grain, K. M., \& Lund, D. E. (2016). The social justice turn: Cultivating "critical hope" in an age of despair. Michigan Journal of Community Service Learning, 23(1), 45-60.

doi: $10.3998 /$ mjcsloa.3239521.0023.104

Gregory, S. (2012). Kony 2012 through a prism of video advocacy practices and trends. Journal of Human Rights Practice, 4(3), 463-468.

doi: $10.1093 /$ jhuman/hus024

Hansen, H. P., Ramstead, J., Richer, S., Smith, S. \& Stratton, M. (2001). Unpacking participatory research in education. Interchange, 32(3), 295-322. Retrieved from https://link.springer.com/article/10.1023/A:1012499200443

Huckle, J. \& Wals, A. E. J. (2015). The UN Decade of Education for Sustainable Development: business as usual in the end. Environmental Education Research, 21(3), 491-505.

doi: $10.1080 / 13504622.2015 .1011084$

International Youth White Paper on Global Citizenship. (2017). Centre for Global Education/Taking it Global. Retrieved from: http://www.epageflip.net/i/796911-internationalyouth-white-paper-on-global-citizenship.

Jickling, B., \& Wals, A. E. J. (2008). Globalization and environmental education: Looking beyond sustainable development. Journal of Curriculum Studies, 40(1), 1-21.

doi: 10.1080/00220270701684667

Kuleta-Hulboj, M. (2016). The global citizen as an agent of change: Ideals of the global citizen in the narratives of Polish NGO employees. Journal for Critical Education Policy Studies, 14(3), 220-250. Retrieved from https://eric.ed.gov/?id=EJ1123657

Lau, S. M. C., \& Stille, S. (2014). Participatory research with teachers: Toward a pragmatic and dynamic view of equity and parity in research relationships. European Journal of Teacher Education, 37(2), 156-170.

doi: 10.1080/02619768.2014.882313 
Madsen, K. D. (2013). Unfolding education for sustainable development as didactic thinking and practice. Sustainability, 5, 3771-3782.

doi: 10.3390/su5093771

Matthews, J. (2011). Hybrid Pedagogies for Sustainability Education. Review of Education, Pedagogy, and Cultural Studies, 33(3), 260-277.

doi: 10.1080/10714413.2011.585288

Mignolo, W. D. (2011). The darker side of Western modernity: Global futures, decolonial options. London, United Kingdom: Duke University Press.

Niens, U. \& Reilly, J. (2012). Education for global citizenship in a divided society? Young people's views and experiences. Comparative Education, 48(1), 103-118.

doi: 10.1080/03050068.2011.637766

Pashby, K. (2018). Global Citizenship Education as a UNESCO Key Theme: More of the Same or Opportunities for Thinking 'Otherwise'? In L. Shultz and T. Pilay (Eds.), Global Citizenship, Common Wealth and Uncommon Citizenships (pp. 160-174). Leiden, The Netherlands: Koninklijke Brill NV.

Pashby, K. \& Sund, L. (2019a). Bridging 4.7 in Teacher Education: Engaging critical scholarship in Education for Sustainable Development and Global Citizenship. In P. Bamber (Ed.), Teacher Education for Sustainable Development and Teacher Education (pp. 99-112). London: Routledge.

Pashby, K. \& Sund, L. (2019b). Teaching for sustainable development through ethical global issues pedagogy: A resource for secondary teachers. Retrieved from https://www2.mmu.ac.uk/esri/teacher-resource/

Pashby, K. \& Sund, L. (2020a). Critical GCE in the era of SDG 4.7: Discussing HEADSUP with secondary teachers in England, Finland, and Sweden. In D. Bourn (Ed.), The Bloomsbury Handbook of Global Education and Learning (pp. 314-326). New York: Bloomsbury.

Pashby, K. \& Sund, L. (2020b). Decolonial options and challenges for ethical global issues pedagogy in northern Europe secondary classrooms. Nordic Journal of Comparative International Education, 4(1), 66-83.

doi: $10.7577 /$ njcie. 3554

Pashby, K., Sund, L. \& Corcoran. S. (2019). Teaching for sustainable development through ethical global issues pedagogy: Participatory research with teachers. [Report]. Retrieved from https://www2.mmu.ac.uk/media/mmuacuk/content/documents/education/final-mmu-report-baproject-teaching-for-sustainable-development-through-ethical-global-issues-pedagogy.pdf

Reilly, J. \& Niens, U. (2014). Global citizenship as education for peacebuilding in a divided society: structural and contextual constraints on the development of critical dialogic discourse in schools. Compare: A Journal of Comparative and International Education, 44(1), 53-76. 
doi: $10.1080 / 03057925.2013 .859894$

Sharma, N. (2020). Integrating Asian Perspectives Within UNESCO-led Discourse and Practice of Global Citizenship Education: Taking Gandhi and Ikeda as Examples. In D. Bourn (Ed.), The Bloomsbury Handbook of Global Education and Learning (pp. 90-102). New York:

Bloomsbury.

Shultz, L. \& Pillay, T. (2018). Global citizenship, common wealth, and uncommon citizenships: An introduction. In L. Shultz and T. Pillay (Eds.), Global citizenship, common wealth and uncommon citizenships (pp. 1-8) Leiden, The Netherlands: Koninklijke Brill NV.

Shultz, L.; Pillay, T.; Karsgaard, C.; \& Pashby, K. (2020). A Global Youth Deliberation and Their International Youth Position Paper on Global Citizenship. In J. Myers (Ed.) Research on Teaching Global Issues: Pedagogy for Global Citizenship Education. Charlotte, North Carolina: Information Age.

Sund, L. (2016). Facing global sustainability issues: teachers' experiences of their own practices in environmental and sustainability education. Environmental Education Research, 22(6), 788805.

doi: $10.1080 / 13504622.2015 .1110744$

Sund, L. \& Pashby, K. (2020). Delinking global issues in northern Europe classrooms. Journal of Environmental Education, 51(02), 156-170.

doi: 10.1080/00958964.2020.1726264

Truong-White, H. \& McLean, L. (2015). Digital storytelling for transformative global citizenship education. Canadian Journal of Education, 38, 1-28.

doi: 10.2307/canajeducrevucan.38.2.11

UNESCO. (2014). Global Citizenship Education: Preparing learners for the challenges of the twenty-first century. Retrieved from

http://unesdoc.unesco.org/images/0022/002277/227729E.pdf.

UNESCO. (2016). Global Monitoring Report: Target 4.7- Sustainable Development and Global Citizenship. Retrieved from https://gem-report-2016.unesco.org/en/chapter/target-4-7-

sustainable-development-and-global-citizenship/.

Wageningen. Retrieved from

https://arjenwals.files.wordpress.com/2016/02/8412100972_rvb_inauguratie-

wals_oratieboekje_v02.pdf

Wals, A.E.J. (2015) Beyond Unreasonable Doubt Education and Learning for Socio-Ecological Sustainability in the Anthropocene. Inaugural address held upon accepting the personal Chair of Transformative Learning for Socio-Ecological Sustainability at Wageningen University, 
Van Poeck, K., \& J. Vandenabeele. (2012). Learning from Sustainable Development: Education in the light of public issues. Environmental Education Research, 18(4), 541-552.

doi: $10.1080 / 13504622.2011 .633162$

Von Engelhardt, J., \& Jansz, J. (2014). Challenging humanitarian communication: An empirical exploration of Kony 2012. International Communication Gazette, 76(6), 464-484.

doi: $10.1177 / 1748048514533861$

\section{KEY TERMS AND DEFINITIONS}

Colonial Matrix of Power: Concept developed by Aníbal Quijano to represent the geographical, political and onto-epistemological extension of western domination, through four interrelated domains: economy, authority, gender/sexuality and knowledge.

Decolonial praxis: Reflexive world interventions that seek to target and dismantle the colonial matrix of power. Praxis requires a continuous learning/unlearning and critical examination of our thinking and actions, in order to avoid the reproduction of the very colonial systems it is trying to undo. It requires decentring western rationalities and centring other ways of knowing, being and relating.

Education for Sustainable Development (ESD): Education field concerned with the preparation of education systems to face global challenges, and the promotion of a sustainable future. The field of ESD is a contested one, and practice often takes on different and opposing approaches. In this chapter, we adopt a critical approach that is informed by decolonial theory. Critical approaches in ESD are often associated with the term Environmental and Sustainability Education.

Global Citizenship Education (GCE): The meaning of global citizenship education is complex and contested, and the field encompasses a set of different, at times contradictory, practices. However, the term is largely understood to mean education about global issues (e.g. poverty, environment, health), with a focus on the relations between local and global contexts. This chapter takes a critical approach to GCE, that is informed by decolonial theory.

HEADSUP: Pedagogical tool designed by Vanessa Andreotti that aims to support a more complex and ethical analysis of representations of global issues. It centres seven problematic tendencies that contribute to the reproduction of unequal and harmful forms of relation, through the creation of an 'us' (in the 'global north') and a 'them' (in the 'global south'): Hegemony, Ethnocentrism, Ahistoricisim, Depoliticisation, Salvationism, Uncomplicated solutions.

Modernity/ Coloniality: Dyad concept developed by Walter Mignolo that represents the ontoepistemological frame on which our present world is built. It comprises of modernity - a selfserving narrative of teleological and seamless progress, leading to ever more civilised and prosperous societies, that is based on universal principles and a dualist logic that separates subject and object, reason and emotion, human and nature; and coloniality - the violent systems of oppression on which modernity is built, e.g. slavery, colonialism, racism. As Walter Mignolo puts it, coloniality represents the dark side of modernity. 
Sustainable Development Goals (SDG): Goals defined as part of the United Nation's 2030 Agenda for Sustainable Development, which set a commitment to eradicate world poverty through a strong emphasis on the promotion of economic, social and environmental sustainable development. Of the 17 goals defined in the agenda 2030, goal 4 (inclusive and equitable quality education and lifelong learning opportunities for all) has particular relevance for this chapter, particularly target 4.7 , which states by 2030 , all learners should have acquired the knowledge and skills needed to promote sustainable development. The target suggests that this can be achieved, among other forms, through education for sustainable development and global citizenship.

\section{ENDNOTES}

\footnotetext{
${ }^{1}$ We use the term 'Global North' as a way to refer to geopolitical areas whose knowledge, economy and politics have been priviledged, naturalized and projected onto others areas, recognizing it is both an imperfect term and can reproduce a binary of 'Global North' and 'Global South' as demonstrated by the use of single quotations marks; however, it attends to the power relations at the heart of the project.

${ }^{2}$ The Kony 2012 video created by NGO Imaginary Children was shared and viewed over 100 million times in 10 days, largely by well-intended youth in 'Global North' contexts (Von Engelhardt and Jansz, 2014). The video, aiming to make warlord Joseph Kony a household name and to stop exploitation of child soldiers, was criticized for presenting a simplistic view with the NGO itself criticized over use of the funds raised (Gregory, 2012).
} 